Marzanna Poniatowicz*

Maria Jastrzębska**

\title{
Zadłużenie jednostek samorządu terytorialnego i jego determinanty
}

Local self-government debt and its determinants

The paper examines the prerequisites and effects of indebtedness of local government units in Poland, as well as identifies the determinants of their indebtedness, divided into legal-financial, political, economic-social and organisational-management ones. The level of indebtedness of these units in the years 2003-2020 is also presented. Cities with powiat status and municipalities are most heavily indebted, which is primarily related to local government investments carried out by them.

\begin{tabular}{|c|c|}
\hline DOI & https://doi.org/10.31268/StudiaBAS.2021.40 \\
\hline Słowa kluczowe & $\begin{array}{l}\text { deficyt i dług lokalny, determinanty długu lokalnego, lokalne reguły } \\
\text { fiskalne }\end{array}$ \\
\hline Keywords & $\begin{array}{l}\text { deficit and debt of local governments, determinants of local } \\
\text { government debt, local fiscal rules }\end{array}$ \\
\hline 0 autorkach & $\begin{array}{l}\text { * profesor dr hab., Uniwersytet w Białymstoku · } \\
凶 \text { m.poniatowicz@uwb.edu.pl • ORCID 0000-0002-8695-5224 } \\
\text { ** doktor hab., prof. PG, Politechnika Gdańska · } \\
\bigotimes \text { maria.jastrzebska@zie.pg.gda.pl • } \\
\text { ORCID 0000-0002-0027-930X }\end{array}$ \\
\hline
\end{tabular}

Artykuł został udostępniony na licencji Creative Commons - Uznanie Autorstwa 3.0 Polska (CC BY 3.0 PL).

\section{Wstęp}

Wzrost aktywności inwestycyjnej jednostek samorządu terytorialnego (JST), wynikający z rosnących potrzeb społecznych, dążenia do zmniejszania luki rozwojowej oraz wykorzystania środków europejskich, skłania JST do zaciągania długu. Wpływ na korzystanie z instrumentów dłużnych przez JST mają również inne uwarunkowania: rozszerzenie zakresu zadań nakładanych na samorząd terytorialny, rosnące koszty usług publicznych, spadek dynamiki wzrostu dochodów własnych JST, niekorzystne dla finansów samorządowych zmiany w systemie podatkowym, skłonność do stosowania liberalnej lokalnej polityki podatkowej, niska skuteczność egzekwowania należności podatkowych itp. Celem artykułu jest wskazanie przyczyn i skutków zadłużania się JST, a także identyfikacja i klasyfikacja determinant długu lokalnego.

Na poziom, strukturę i dynamikę długu JST oddziałuje wiele czynników. Część z nich ma charakter wewnętrzny i zależy od specyfiki jednostki samorządu terytorialnego oraz lokalnej polityki długu, natomiast część pozostaje poza jej kontrolą i wpływem. W literaturze przedmiotu różnie klasyfikuje się czynniki z tym związane ${ }^{1}$. Na potrzeby niniejszego opracowania zaproponowano podział determinant długu JST na następujące kategorie:

1 Por. R.A. Cropf, G.D. Wendel, The Determinants of Municipal Debt Policy: A Pooled Time-Series Analysis, „Environment and Planning" 1998, t. 16, nr 2, https://doi.org/10.1068/c160211, s. 211-224; M.T. Balaguer-Coll, 
- prawnofinansowe,

- polityczne,

- ekonomiczno-społeczne,

- organizacyjno-zarządcze.

\section{Przesłanki i skutki wykorzystywania długu jako zewnętrznego źródła finansowania jednostek samorządu terytorialnego}

W literaturze przedmiotu określa się wiele przesłanek przesądzających o konieczności zadłużania się JST. Za kluczowe w tym zakresie uznaje się zwykle kilka z nich.

Po pierwsze, do zaciągania długu przez JST skłania brak wystarczających funduszy własnych jednostek na pokrycie wydatków związanych z realizowaniem zadań publicznych. W tym kontekście dług służy dwóm zasadniczym celom: zaspokajaniu bieżących potrzeb wydatkowych oraz finansowaniu inwestycji samorządowych². W nawiązaniu do tego B.Z. Filipiak wspomina o bieżącej roli długu krótkoterminowego, wspomagającego bieżące regulowanie zobowiązań w okresach przejściowego deficytu bieżącego, oraz o inwestycyjnej roli długu długoterminowego ${ }^{3}$. Co charakterystyczne, w dostępnej literaturze przedmiotu dług zaciągany na cele inwestycyjne jest najczęściej oceniany pozytywnie jako dług dobry, prorozwojowy i konstruktywny, natomiast dług służący równoważeniu budżetu bieżącego - negatywnie, jako dług zły i destruktywny4 ${ }^{4}$. Do takiego rozróżnienia długów nawiązywał m.in. R. Kiyosaki, który dzielił długi na dwie kategorie, tj. dobre, czyniące nas bogatymi oraz złe, czyniące nas biednymi ${ }^{5}$. Wskazywał jednocześnie, że tzw. inteligencja finansowa przy wykorzystywaniu instrumentów dłużnych polega na umiejętności ich rozróżniania. Należy dodać, że kryterium przeznaczania długu na cele bieżące lub inwestycyjne nie jest wystarczające do oceny długu. Ważne jest również, aby instrumenty dłużne były wykorzystywane przez JST zgodnie z rachunkiem ekonomicznym oraz z zastosowaniem proefektywnościowych mechanizmów i instrumentów zarządzania, tak aby dług mógł być instrumentem zwiększającym skuteczność świadczenia dóbr i usług publicznych. W nawiązaniu do tych kwestii A. Borodo dzieli dług samorządowy na rentowny i nierentowny ${ }^{6}$.

D. Prior, E. Tortosa-Ausina, On the Determinants of Local Government Debt: Does One Size Fit All?, „International Public Management Journal" 2016, t. 19, nr 4, s. 513-542, https://doi.org/10.1080/10967494.2015.1104403.

2 J. Szołno-Koguc, Przyczyny oraz możliwości zadłużania się jednostki samorządu terytorialnego, „Annales Universitatis Mariae Curie-Skłodowska. Sectio H. Oeconomia" 2013, t. 47, nr 1, s. 202.

3 B.Z. Filipiak, Dług jako determinanta stabilności systemu finansów samorzqdowych, „Kwartalnik Kolegium Ekonomiczno-Społecznego. Studia i Prace" 2017, nr 1, s. 16, https://doi.org/10.33119/KKESSiP.2017.1.1.

4 Por. M. Poniatowicz, Dobry dług versus zły dług, czyli o specyfice zadłużenia sektora samorzadowego [w:] Ekonomiczne i prawne uwarunkowania i bariery redukcji deficytu i długu publicznego, red. J. Szołno-Koguc, A. Pomorska, Wolters Kluwer, Warszawa 2011, s. 488-500.

5 Por. R. Kiyosaki, S. Lechter, Rich Dad, Poor Dad: What the Rich Teach Their Kids About Money-That the Poor and Middle Class Do Not!, Warner Business Books, 2000.

6 A. Borodo, Samorzad terytorialny. System prawnofinansowy, LexisNexis, Warszawa 2006, s. 217-218. 
Po drugie, istotną przesłanką zadłużania się JST jest występująca w Polsce luka infrastrukturalna w zakresie inwestycji publicznych ${ }^{7}$. Miały na nią wpływ zarówno uwarunkowania historyczne, jak i błędy poczynione przez decydentów publicznych. Wprawdzie od momentu przystąpienia Polski do Unii Europejskiej (UE) zakres wspomnianej luki systematycznie się zmniejsza, ale wciąż stanowi ona istotny impuls do podejmowania decyzji zadłużeniowych przez JST związanych z realizacją projektów inwestycyjnych służących jej ograniczaniu. Należy dodać, że polski samorząd terytorialny jest kluczowym inwestorem publicznym odpowiadającym za $50,2 \%$ ogółu inwestycji publicznych w Polsce (dane za 2018 r.) $)^{8}$.

Po trzecie, za wykorzystaniem instrumentów dłużnych w procesie finansowania samorządowych inwestycji przemawia specyfika tych inwestycji. W literaturze przedmiotu wskazuje się na następujące ich cechy: wysoką kapitałochłonność, długi cykl inwestycyjny (czasochłonność), długi okres zwrotu z zainwestowanego kapitału, wysokie ryzyko inwestycyjne, niepodzielność nakładów, niestabilność i nierównomierne rozłożenie w czasie wydatków budżetowych z nimi związanych itp. ${ }^{9}$ Wykorzystywanie przez JST instrumentów dłużnych ewidentnie skraca proces inwestycyjny, a tym samym obniża jego koszty oraz pozwala na „odłożenie w czasie” obciążeń podatkowych mieszkańców wspólnoty samorządowej. Bez wykorzystywania instrumentów dłużnych wysokość tych obciążeń jako źródła finansowania inwestycji samorządowych musiałaby się diametralnie zmieniać w poszczególnych latach, co byłoby trudne do zaakceptowania ze względów politycznych (szerzej na ten temat w części Polityczne determinanty długu JST).

Po czwarte, przy analizie przesłanek zadłużania się JST przytaczany jest często argument idei równości międzypokoleniowej (ang. intergovernmental equity). Zgodnie z nim inwestycje publiczne finansowane za pomocą instrumentów dłużnych wiążą się nie tylko z wydatkami publicznymi ponoszonymi w chwili ich realizacji, lecz także z określonymi kosztami i korzyściami, które staną się udziałem przyszłych pokoleń. Amerykański ekonomista, laureat Nagrody Nobla P. Krugman uważa wręcz, że przez zaniedbanie inwestycji publicznych (dotyczy to również inwestycji samorządowych) wyrządza się znacznie więcej szkód przyszłym pokoleniom niż przez przerzucanie na nie kosztów obsługi zadłużenia. W swoim artykule opublikowanym w 2013 r. na łamach dziennika "The New York Times" stwierdza on: „Fiscal policy is, indeed, a moral issue, and we should be ashamed of what we're doing to the next generation's economic prospects. But our sin involves investing too little, not borrowing too much” (tłum. aut.: „Polityka fiskalna jest w istocie kwestią moralną i powinniśmy się wstydzić tego, co robimy z perspektywami gospodarczymi następnego pokolenia. Ale nasz grzech polega na tym, że inwestujemy za mało, a nie pożyczamy za dużo" $)^{10}$.

7 Por. J. Sierak, Komunalna luka infrastrukturalna a możliwości budżetowe gmin w jej ograniczaniu, Oficyna Wydawnicza SGH, Warszawa 2019, s. 334-337; J.A. Wachowska, Luka infrastrukturalna inwestycji publicznych w Polsce, "Ekonomiczne Problemy Usług” 2013, nr 108, s. 329-343.

8 OECD, Better Governance, Planning and Services in Local Self-Governments in Poland, Paryż 2021, s. 16, https:// doi.org/10.1787/550c3ff5-en.

9 K. Brzozowska, Partnerstwo publiczno-prywatne. Przesłanki, możliwości, bariery, CeDeWu, Warszawa 2013, s. 53-54; K. Witkowski, Inwestycje infrastrukturalne w realizacji usług publicznych, „Studia Lubuskie” 2011, t. 7, s. 274.

10 P. Krugman, Cheating Our Children, „New York Times” 2013, March 28th, www.nytimes.com/2013/03/29/ opinion/krugman-cheating-our-children.html [dostęp: 26 listopada 2021 r.]. 
Po piąte, popularnym argumentem za zadłużaniem się JST w polskich realiach jest także konieczność zwiększenia dostępu JST do środków pomocowych Unii Europejskiej. W tym kontekście dług samorządowy traktowany jest przez decydentów publicznych jako ważny instrument zwiększający zdolności absorpcyjne JST ${ }^{11}$. Wynika to m.in. z obowiązującej w ramach polityki strukturalnej UE zasady współfinansowania projektów przez beneficjentów w formule zapewnienia przez nich tzw. wkładu własnego. Wymóg ten dotyczy również beneficjentów samorządowych - jeśli chcą sprostać wyzwaniu i pokryć wspomniany wkład, to muszą wykorzystać kredyt inwestycyjny.

Po szóste, przytaczany jest również argument, że dług jest instrumentem stabilizowania systemu finansowego JST w sytuacjach nadzwyczajnych (kryzysowych) ${ }^{12}$. Zgodnie z wybranymi teoriami ekonomicznymi (nowoczesna teoria monetarna, neokeynesizm) zwiększanie poziomu zadłużenia publicznego w takich sytuacjach jest uzasadnione, ponieważ sprzyja stymulowaniu gospodarki. W tym ujęciu dług jest postrzegany jako instrument finansowania deficytów budżetowych, będących rezultatem nadzwyczajnych wydatków publicznych związanych z łagodzeniem negatywnych skutków kryzysu. Dyskusja nad tą funkcją długu publicznego nabrała szczególnego znaczenia w sytuacji kryzysu wywołanego wirusem SARS-CoV-2. Należy jednak wyraźnie podkreślić, że obserwowany w Polsce wzrost tzw. długu pandemicznego to przede wszystkim rezultat rządowych pomocowych pakietów fiskalnych (tzw. tarcz antykryzysowych), stosowanych w walce z pandemią ${ }^{13}$.

W opisanych powyżej przesłankach uzasadniających wykorzystywanie długu w gospodarce finansowej JST akcentuje się przede wszystkim pozytywne aspekty z tym związane, nie można jednak pominąć tych negatywnych. Nadmierne zadłużenie JST ma zwykle trwałe i negatywne konsekwencje dla gospodarki lokalnej. Jego skutkiem jest często utrata płynności finansowej JST (w krótkiej perspektywie) oraz niewypłacalność (w długiej perspektywie). Obniża się wiarygodność i zdolność kredytowa JST oraz drastycznie rosną koszty obsługi zadłużenia. W rezultacie często następuje utrata zdolności JST do realizowania podstawowych zadań publicznych na dotychczasowym poziomie ilościowym i jakościowym ${ }^{14}$. Jako inne zagrożenie związane z nadmier-

11 Por. A. Wojtach, Uwarunkowania zdolności absorpcyjnej funduszy unijnych w administracji publicznej, „Zarządzanie i Finanse" 2012, R. 10, nr 3, s. 429-442.

12 B.Z. Filipiak, op. cit., s. 16.

13 O skutkach kryzysu COVID-19 dla budżetów samorządowych mówi się w kontekście pandemicznego „efektu nożycowego" (ang. the pandemic "scissor effect"), por. OECD and European Committee of the Regions, The Impact of the COVID-19 Crisis on Regional and Local Governments: Main Findings from Joint COR-OECD Survey, November 2020, s. 3-5. W Polsce zjawisko to obserwuje się przede wszystkim w największych miastach na prawach powiatu. Przejawia się ono drastycznym wzrostem wybranych kategorii wydatków budżetowych JST, związanych stricte z ograniczaniem skutków kryzysu pandemicznego (np. wydatków samorządowych na opiekę zdrowotną, pomoc społeczną, wsparcie przedsiębiorców, wyposażenie niezbędne do zapewnienia bezpieczeństwa epidemicznego, dezynfekcję przestrzeni publicznych itp.) i jednoczesnym spadkiem dochodów własnych (niższe wpływy podatkowe od przedsiębiorców spowodowane ograniczeniem ich działalności gospodarczej w związku z lockdownem, niższe dochody z mienia komunalnego, niższe wpływy z opłat za korzystanie z komunikacji miejskiej, opłat parkingowych itp.).

14 Jako przykład może posłużyć gmina Ostrowice (województwo zachodniopomorskie), którą zlikwidowano w 2019 r. ze względu na nadmierne zadłużenie w parabankach i włączono do dwóch sąsiednich gmin (Drawsko Pomorskie i Złocieniec). Dotychczas był to pierwszy i jedyny przypadek tego typu w Polsce. 
nym zadłużeniem wskazuje się wzrost lokalnego sektora publicznego ponad rozmiar optymalny (definiowany przez poziom obciążenia podatkami lokalnymi) ${ }^{15}$. Nadmierny dług implikuje również wystąpienie efektu „wypychania” (ang. crowding out effect) inwestycji prywatnych z rynku lokalnego - JST są lepszymi klientami dla banków niż inwestorzy prywatni m.in. ze względu na brak możliwości bankructwa, a w rezultacie - niższe ryzyko kredytowe ${ }^{16}$.

Jeśli kryzysy zadłużeniowe dotyczą jednocześnie wielu JST, wówczas może to stanowić istotne zagrożenie dla stabilności fiskalnej całego systemu finansów publicznych. Nawiązuje do tego m.in. teoria federalizmu fiskalnego, w której wspomniane zagrożenia są rozpatrywane w ramach problematyki podziału ryzyka pomiędzy poszczególne podsektory władzy publicznej (ang. intergovernmental risk sharing) ${ }^{17}$. Opisywany jest tu problem pokusy nadużycia (ang. moral hazard). W podsektorze samorządowym zjawisko to można uznać za istotny czynnik osłabiający chęć prowadzenia odpowiedzialnej polityki zadłużeniowej przez decydentów publicznych, a jako przyczyny jego występowania wskazuje się nie tylko mechanizmy przejmowania zobowiązań finansowych JST przez budżet krajowy, lecz także prawnie uwarunkowany brak zdolności upadłościowej i możliwości ogłoszenia bankructwa przez JST w wielu państwach (również w Polsce). Jak podkreśla V. Tanzi, nadmierna aktywność pożyczkowa JST najczęściej bierze się właśnie z przeświadczenia, że w przypadku pojawienia się ewentualnych trudności ze spłatą zadłużenia władze samorządowe będą mogły liczyć na pomoc rządu krajowego, a jako przykłady negatywnych skutków takiej strategii podaje kryzysy finansów lokalnych w Argentynie i Brazylii ${ }^{18}$.

\section{Zadłużenie jednostek samorządu terytorialnego w latach 2003-2020}

W okresie 2003-2020 budżety JST łącznie zamknęły się nadwyżką w latach: 2004, 2007, 2015, 2016 i 2020, a więc w ciągu 18 lat zaledwie pięć razy (wykres 1). W 2004 r. było to związane ze zmianą systemu dochodów JST i znacznym wzrostem dochodów własnych, a w 2007 r. był to rezultat dobrej koniunktury gospodarczej, w wyniku której dynamicznie rosły dochody JST, a zwłaszcza dochody podatkowe. W latach 2015-2016 nadwyżka budżetowa wystąpiła dzięki wykonaniu dochodów ponad plan i stopniowej poprawie koniunktury gospodarczej. Natomiast w 2020 r. nadwyżka wynikała z tytułu pozyskanych środków z Funduszu Dróg Samorządowych (aktualna nazwa - Rządowy Fundusz Rozwoju Dróg) i Rządowego Funduszu Inwestycji Lokal-

15 O rozmiarze wspomnianego sektora przesądza m.in. udział wydatków publicznych w PKB, a rosnące koszty obsługi długu lokalnego oznaczają większe wydatki bieżące w tym sektorze.

16 B. Guziejewska, Ograniczenia w zaciaganiu długu przez samorząd terytorialny - aspekty teoretyczne a rozwiqzania w praktyce [w:] Podsektor samorzq̨dowy w sektorze finansów publicznych w warunkach akcesji Polski do Unii Europejskiej, red. L. Patrzałek, Wydawnictwo Wyższej Szkoły Bankowej, Poznań-Wrocław 2006, s. 228-229.

17 Por. T. Persson, G. Tabellini, Federal Fiscal Constitutions: Risk Sharing and Moral Hazard, "Econometrica” 1996, t. 64, nr 3, s. 623-646, https://doi.org/10.2307/2171864; S. Bucovetsky, Federalism, Equalization and Risk Aversion, „JJournal of Public Economics" 1998, t. 67, nr 3, s. 301-328; N. Zahariadis, The Politics of Risk-sharing: Fiscal Federalism and the Greek Debt Crisis, "Journal of European Integration" 2013, t. 35, nr 3, s. 271-285, https://doi.org/10.1080/07036337.2013.774787.

18 V. Tanzi, On Fiscal Federalism: Issues To Worry About, s. 11, https://www.imf.org/external/pubs/ft/seminar/2000/fiscal/tanzi.pdf [dostęp: 26 listopada 2021 r.]. 
nych oraz z niższego, niż pierwotnie zakładano, wykonania wydatków inwestycyjnych. Wzrost deficytu budżetowego w badanym okresie był najwyższy w latach 2009-2011, kiedy to istotnie pogorszyła się koniunktura gospodarcza, i wyniósł ponad 10-14 mld zł (w badanym okresie wysoki był również deficyt w 2018 r., ale na poziomie zdecydowanie niższym, bo ponad $7 \mathrm{mld}$ zł). Największy wzrost poziomu deficytu budżetowego w latach 2003-2020 zaobserwowano przede wszystkim w gminach i miastach na prawach powiatu, które łącznie gromadzą i wydatkują ponad 80\% środków publicznych ogółem będących w dyspozycji JST.

W badanym okresie systematycznie rosły zobowiązania JST ogółem, z wyjątkiem lat 2015, 2016, 2017 (wykres 2). Szczególnie wysoki wzrost poziomu zobowiązań ogółem JST można zaobserwować w okresie pogorszenia koniunktury gospodarczej, tj. w latach 2009, 2010 i 2011, kiedy to występował bardzo wysoki poziom deficytu budżetowego, a zobowiązania ogółem JST łącznie rosły rocznie o 20-40\% w porównaniu z rokiem poprzednim (wykres 3). Natomiast w latach 2012-2014 wzrost ten był zdecydowanie niższy, bo o 2-4\%. Warto zauważyć, że w latach 2018-2020 ponownie wystąpił wysoki wzrost poziomu zobowiązań ogółem JST, bo o ok. 8-10\% w porównaniu z rokiem poprzednim. Szczególnie niepokojący jest wzrost w 2020 r. w stosunku do 2019 r., zwłaszcza że wydatki inwestycyjne wykonano na poziomie zdecydowanie niższym, niż zakładano. Warto też zauważyć, że w latach, kiedy odbywały się wybory samorządowe (2006, 2010, 2014, 2018), odnotowano relatywnie większe wzrosty poziomów deficytu i zobowiązań ogółem zarówno w odniesieniu do JST łącznie, jak i poszczególnych ich kategorii (wykresy 1 i 2).

\section{Wykres 1. Wynik budżetów JST ogółem i według kategorii JST w latach 2003-2020 (w mln zł)}

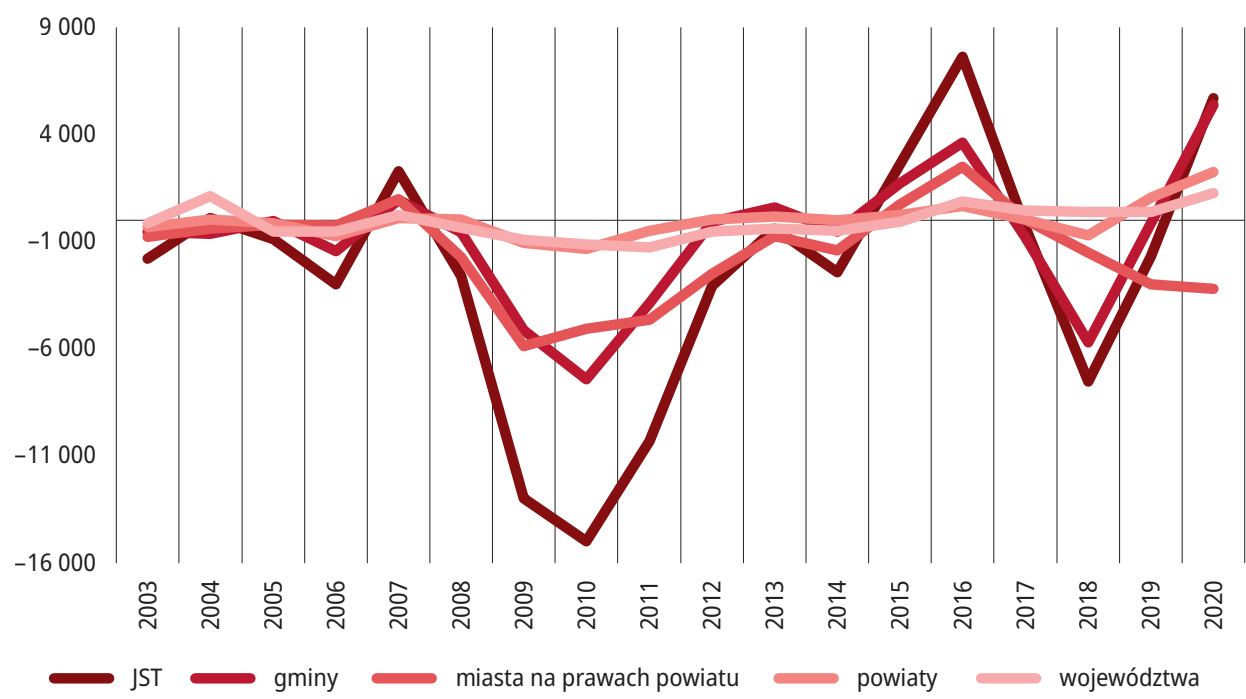

Źródło: opracowano na podstawie informacji o wykonaniu budżetów jednostek samorządu terytorialnego za poszczególne lata okresu badawczego, dane Ministerstwa Finansów, www.mf.gov.pl. 
Wykres 2. Zobowiązania ogółem JST według kategorii w latach 2003-2020 (w mln zł)

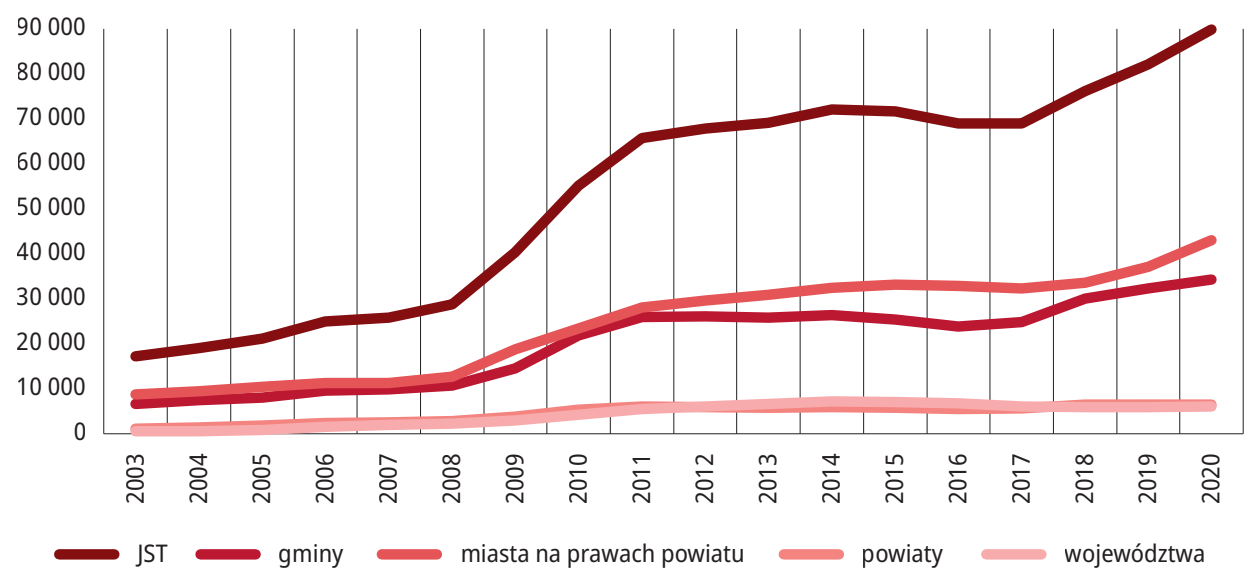

Źródło: opracowano na podstawie informacji o wykonaniu budżetów jednostek samorządu terytorialnego za poszczególne lata okresu badawczego, dane Ministerstwa Finansów, www.mf.gov.pl.

Wykres 3. Dynamika zobowiązań ogółem JST według kategorii w latach 2004-2020 (w \%; rok poprzedni $=100 \%$ )

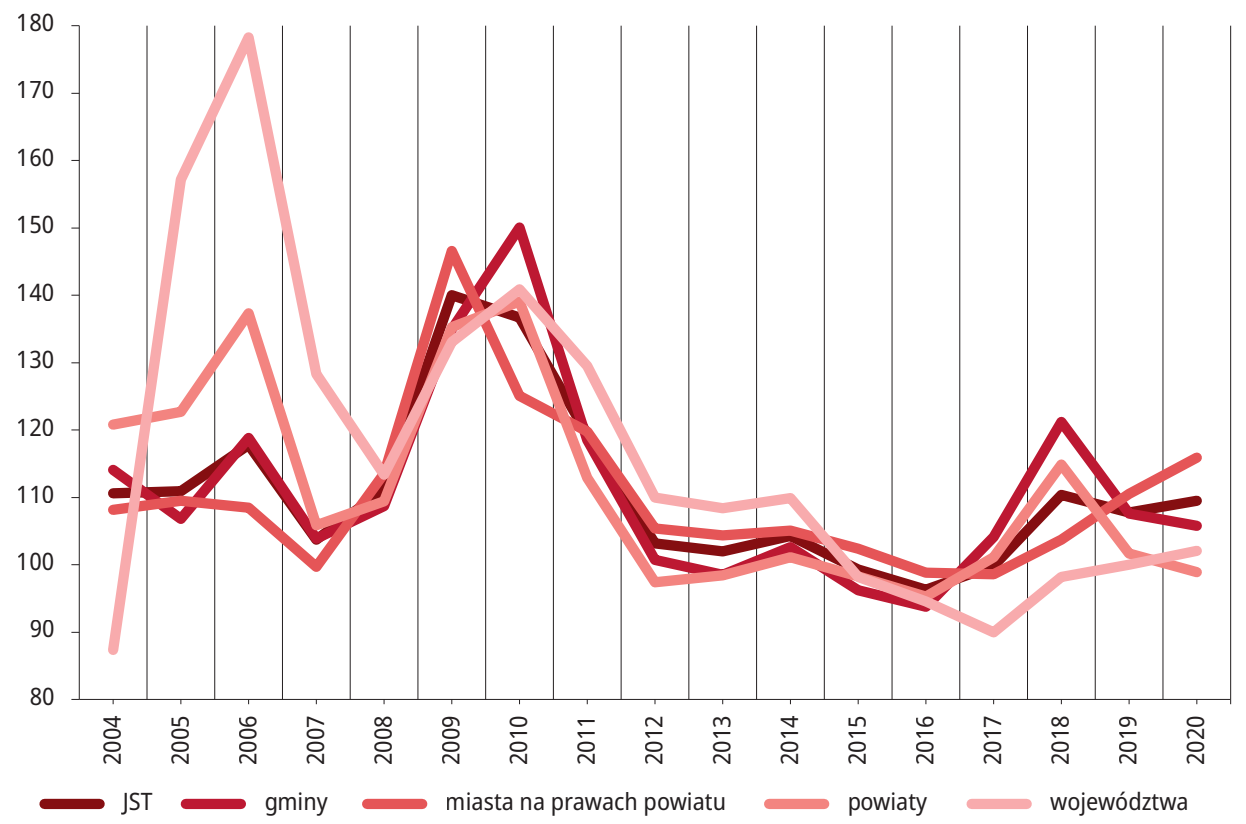

Źródło: opracowano na podstawie informacji o wykonaniu budżetów jednostek samorządu terytorialnego za poszczególne lata okresu badawczego, dane Ministerstwa Finansów, www.mf.gov.pl. 
W całym badanym okresie zobowiązania miast na prawach powiatu były wyższe niż zadłużenie gmin, powiatów i województw. Udział ich zobowiązań w zobowiązaniach ogółem JST łącznie w badanym okresie kształtował się w granicach od 50,9\% w 2003 r. do 47,8\% w 2020 r., przy czym najniższy był w latach 2010-2011 i wynosił ok. 43\% (w tych latach w większym stopniu zadłużały się gminy). Z kolei udział zobowiązań ogółem gmin w zobowiązaniach JST łącznie w latach 2003-2020 wynosił ok. 35-40\%. A zatem ponad 80\% zadłużenia JST ogółem stanowiły zobowiązania miast na prawach powiatu i gmin. Udział zobowiązań ogółem powiatów w zobowiązaniach ogółem JST łącznie stanowił w latach 2003-2020ok. 7-10\%, a województw ok. 3-10\% (wykres 4).

\section{Wykres 4. Udział zobowiązań ogółem według kategorii JST w zobowiązaniach ogółem JST łącznie w latach 2003-2020 (w \%)}

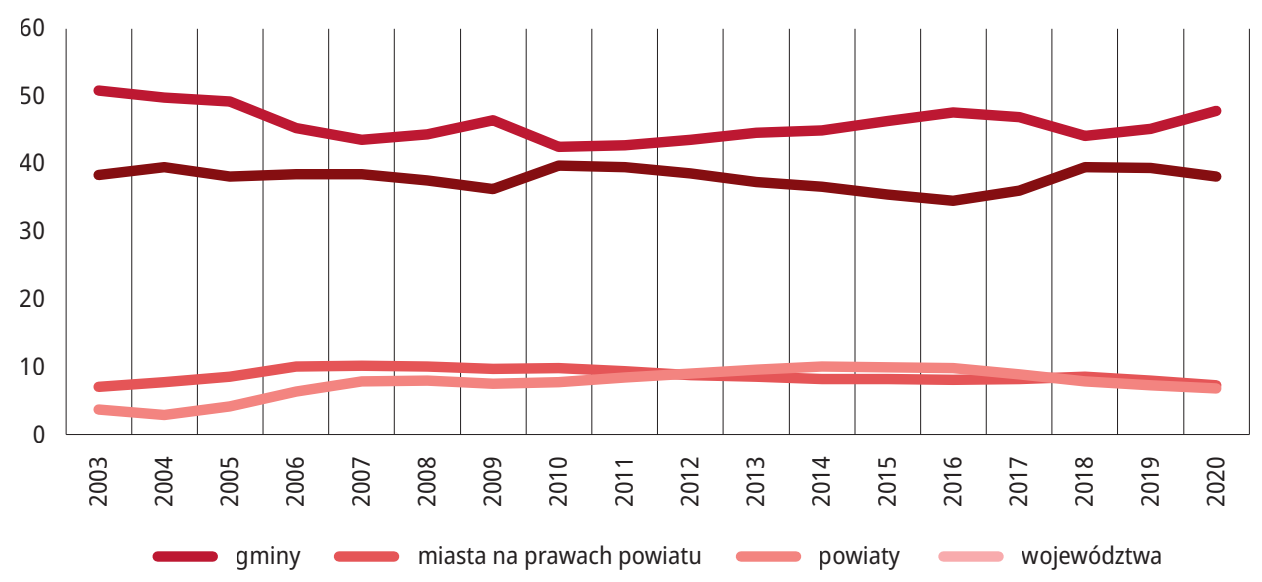

Źródło: opracowano na podstawie informacji o wykonaniu budżetów jednostek samorządu terytorialnego za poszczególne lata okresu badawczego, dane Ministerstwa Finansów, www.mf.gov.pl.

Jednostki samorządu terytorialnego zadłużają się przede wszystkim przez zaciąganie kredytów i pożyczek, a zobowiązania z tego tytułu stanowiły w latach 2003-2020 średnio ponad 80-96\% zobowiązań JST łącznie. Pogorszenie koniunktury gospodarczej w latach 2009-2011 miało wpływ na wybór przez JST instrumentów dłużnych, tj. na częstsze korzystanie z kredytów i pożyczek oraz rzadsze sięganie po emisje dłużnych papierów wartościowych. Jeszcze w latach 2003-2007 zobowiązania z tego tytułu stanowiły ponad 15-16\% zobowiązań ogółem JST łącznie, podczas gdy w latach 2016-2020 już tylko 4-6\% (wykres 5). W miastach na prawach powiatu wprawdzie wciąż jest widoczne zainteresowanie emisją papierów wartościowych dłużnych, ale i w ich przypadku udział zobowiązań z tego tytułu w zobowiązaniach ogółem w ostatnich pięciu latach zmniejszył się z ponad $11 \%$ do $6 \%$. Udział zobowiązań z tytułu papierów wartościowych dłużnych w zobowiązaniach ogółem jest jeszcze niższy w przypadku pozostałych JST, które przecież jeszcze przed 2009 r. chętniej korzystały z tych instrumentów dłużnych (wykres 6). 
Wykres 5. Struktura zobowiązań JST ogółem według tytułów dłużnych w latach 2003-2020 (w \%)

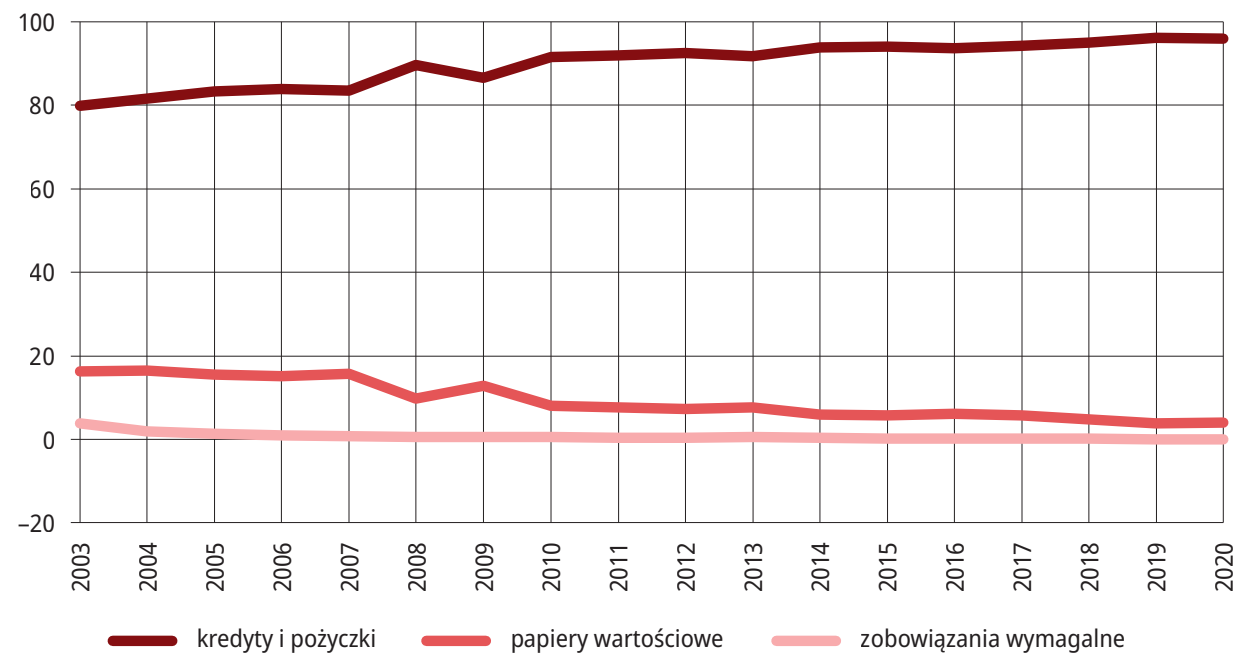

Źródło: opracowano na podstawie informacji o wykonaniu budżetów jednostek samorządu terytorialnego za poszczególne lata okresu badawczego, dane Ministerstwa Finansów, www.mf.gov.pl.

Wykres 6. Udział zobowiązań z tytułu papierów wartościowych w zobowiązaniach ogółem według kategorii JST w latach 2003-2020 (w \%)

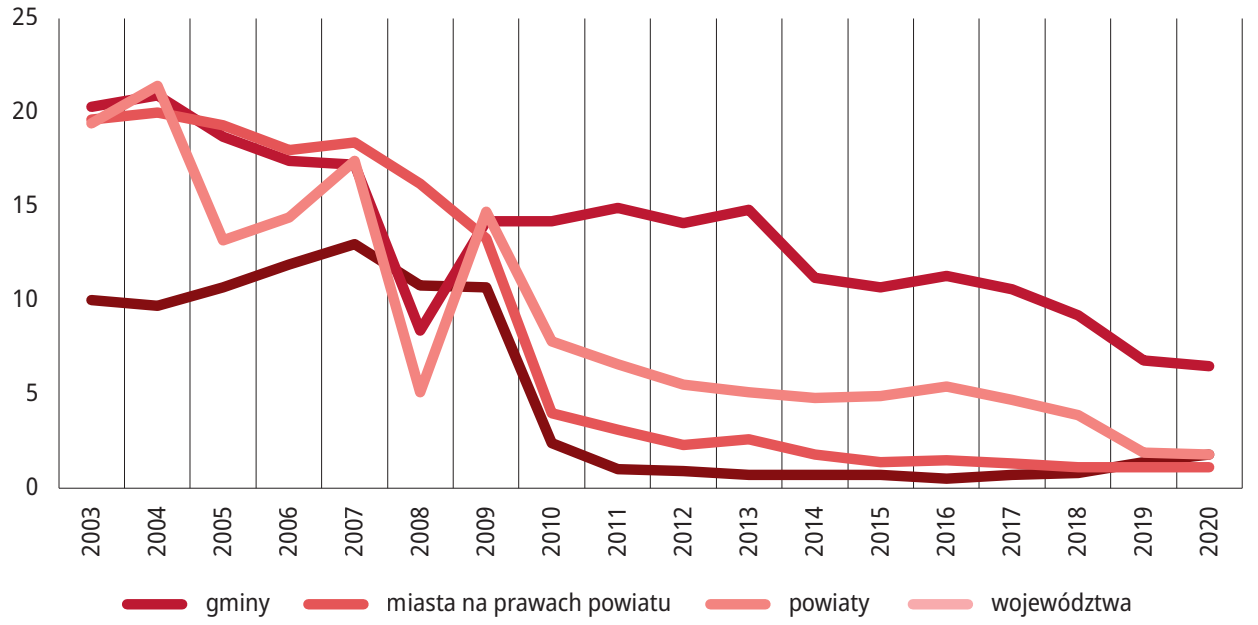

Źródło: opracowano na podstawie informacji o wykonaniu budżetów jednostek samorządu terytorialnego za poszczególne lata okresu badawczego, dane Ministerstwa Finansów, www.mf.gov.pl. 


\section{Prawnofinansowe determinanty długu JST}

W literaturze przedmiotu proponuje się różne instrumenty kontrolowania aktywności pożyczkowej w podsektorze samorządowym. Można je znaleźć m.in. w pracach takich autorów, jak: T. Ter-Minassian i J. Craig ${ }^{19}$, R.J. Singh i A. Plekhanov ${ }^{20}$ czy J. Martinez-Vazquez i V. Vulovic ${ }^{21}$. Wymienia się tam następujące kategorie instrumentów:

- dyscyplinę rynkową (ang. market discipline),

- podejście oparte na współpracy (ang. cooperative approach),

- kontrolę zadłużenia za pomocą reguł fiskalnych (ang. fiscal rules-based borrowing),

- bezpośrednią kontrolę administracyjną (ang. administrative control).

Do pierwszej kategorii instrumentów, tj. dyscypliny rynkowej, nawiązywał w kontekście zadłużenia samorządu terytorialnego T.D. Lane ${ }^{22}$. Podkreślał on, że skuteczność i efektywność oddziaływania tych instrumentów na decyzje zadłużeniowe władz samorządowych wymagają spełnienia określonych warunków. Z jednej strony rynek powinien być wolny i otwarty dla podmiotów publicznych, przy czym żaden z tych podmiotów nie może mieć uprzywilejowanego do niego dostępu, czyli nie można ustanawiać przepisów faworyzujących władze publiczne jako kredytobiorców. Poza tym rynek powinien mieć swobodny dostęp do informacji o sytuacji finansowej publicznych kredytobiorców. Z drugiej strony władze publiczne powinny reagować na sygnały rynkowe. I wreszcie, nie powinno się „ratować za wszelką cenę” podmiotów publicznych zagrożonych niewypłacalnością, ponieważ prowadzi to do wspomnianej wcześniej pokusy nadużycia: zmniejsza się nie tylko motywacja pożyczkodawców do rzetelnej oceny zdolności kredytowej pożyczkobiorców publicznych, lecz także motywacja tych pożyczkobiorców do utrzymania zdolności regulowania swoich zobowiązań finansowych.

Inna kategoria narzędzi ograniczania aktywności w korzystaniu z instrumentów dłużnych przez władze samorządowe wiąże się z podejściem opartym na współpracy. Istota wspomnianych instrumentów sprowadza się do zaangażowania poszczególnych poziomów władzy publicznej w proces określania parametrów i formułowania celów polityki fiskalnej, również w kontekście ponoszenia odpowiedzialności za ich osiągnięcie. W modelu tym istotne znaczenie mają dialog i negocjacje pomiędzy poszczególnymi szczeblami władzy publicznej, np. dotyczące ustalenia konkretnych limitów zadłużenia dla poszczególnych podmiotów podsektora samorządowego.

Zanim zostanie podjęty temat istotnych dla badanego problemu reguł fiskalnych, warto nawiązać do zdecydowanie najbardziej restrykcyjnej formy nadzoru nad zadłużeniem samorządowym, jaką jest bezpośrednia kontrola administracyjna. Przykładami państw ją stosujących

19 T. Ter-Minassian, J. Craig, Control of Subnational Government Borrowing [w:] Fiscal Federalism in Theory and Practice, red. T. Ter-Minassian, International Monetary Fund, Washington 1997, s. 158.

20 R.J. Singh, A. Plekhanov, How Should Subnational Government Borrowing Be Regulated? Some Cross-Country Empirical Evidence, „IMF Staff Papers” 2007, t. 53, nr 3, s. 430-432.

21 J. Martinez-Vazquez, V. Vulovic, How Well Do Subnational Borrowing Regulations Work, „ADBI Working Paper Series" 2016, nr 563, s. 11-17.

22 T.D. Lane, Market Discipline, "IMF Staff Papers” 1993, t. 40, s. 53-88. 
są: Dania, Grecja, Irlandia, Meksyk i Wielka Brytania ${ }^{23}$. Należy dodać, że oddziaływania administracyjne władz centralnych na władze samorządowe mogą przyjmować różną postać. Są nimi przykładowo: odgórne ustalanie limitów ogólnego zadłużenia poszczególnym JST; ścisły przegląd i autoryzacja oraz zatwierdzanie operacji kredytowych samorządu terytorialnego przez władze centralne; ograniczenia administracyjne dotyczące możliwości zadłużania się przez JST na rynkach zagranicznych (np. w Meksyku, w którym istnieje zakaz zaciągania takich pożyczek, lub Indiach i Boliwii, gdzie władza centralna każdorazowo zatwierdza ich warunki) ${ }^{24}$. Skrajnym przypadkiem limitacji zadłużenia samorządowego przez władze centralne jest wprowadzenie zakazu w tym zakresie. Przykładem może być Chile, w którym obowiązuje całkowity zakaz zadłużania się jednostek podsektora samorządowego na cele nie tylko bieżące, lecz także inwestycyjne.

Kolejna kategoria instrumentów to reguły fiskalne. W literaturze przedmiotu definiuje się je jako stałe ograniczenia o charakterze ilościowym lub jakościowym, niezależne od zmieniającej się sytuacji politycznej, wprowadzone na określoną wielkość ekonomiczną ${ }^{25}$. W odniesieniu do podsektora samorządowego analizowane instrumenty określa się terminem lokalnych reguł fiskalnych ${ }^{26}$. Podobnie jak w podsektorze rządowym ich funkcją jest dyscyplinujące oddziaływanie na władze fiskalne, a w tym konkretnym przypadku - limitowanie samorządowych decydentów fiskalnych w aspekcie nie tylko ponoszonych wydatków publicznych, lecz także finansowania deficytów budżetowych oraz zaciągania zobowiązań finansowych.

Reguły fiskalne dzielą się na dwie podstawowe kategorie, tj. reguły ilościowe zwane inaczej regułami numerycznymi (ang. numerical fiscal rules) oraz reguły jakościowe (ang. qualitative fiscal rules). Pierwsze z nich realizowane są w formule określonych limitów fiskalnych odnoszących się zarówno do salda budżetowego, jak i do wielkości długu publicznego, a także wydatków i dochodów publicznych. Z kolei reguły jakościowe to swoiste zasady fiskalne, określające w sposób opisowy pewne ograniczenia, np. precyzujące dopuszczalne sposoby finansowania deficytów budżetowych czy akceptowane cele zaciągania zobowiązań finansowych przez władze publiczne itp.

Do najważniejszych rozwiązań zabezpieczających polskie JST przed utratą płynności i nadmiernym zadłużeniem można zaliczyć:

- regułę co najmniej zrównoważonego wyniku bieżącego budżetu samorządowego, czyli tzw. złotą regułę (ang. golden rule), wprowadzoną do systemu finansów samorządowych od 2011 r.;

- indywidualny wskaźnik zadłużenia (IWZ), który od 2014 r. zastąpił obowiązujące wcześniej limity zadłużenia do dochodów ogółem (60\%) oraz spłaty długu i odsetek do dochodów ogółem (15\%).

23 J. Martinez-Vazquez, V. Vulovic, op. cit., s. 15.

24 R.J. Singh, A. Plekhanov, op. cit., s. 6-7.

25 G. Kopits, S. Symansky, Fiscal Policy Rules, International Monetary Fund, Washington 1998, s. 2.

26 Por. M. Poniatowicz, Reguły fiskalne jako instrument stabilizacji finansowej w sektorze samorzadowym [w:] Stabilność systemu finansowego - instytucje, instrumenty, uwarunkowania, red. A. Alińska, B. Pietrzak, CeDeWu, Warszawa 2012, s. 309-322; P. Galiński, Limitowanie długu jednostek samorzq̨du terytorialnego, „Zarządzanie i Finanse" 2017, t. 15, nr 2, s. 19-31; B. Ciupek, P. Kania, Determinanty reguł fiskalnych w zarzadzaniu zadłużeniem jednostek samorzqdowych, „Prace Naukowe Uniwersytetu Ekonomicznego we Wrocławiu” 2015, nr 404 s. 37-52, https://doi.org/10.15611/pn.2015.404.03. 
Zgodnie z pierwszą z wymienionych zasad fiskalnych, tj. złotą regułą, JST nie mogą uchwalać budżetu, w którym bieżące wydatki nie znajdują pokrycia w dochodach bieżących, powiększonych o nadwyżkę budżetową z lat ubiegłych oraz o wolne środki, wynikające z rozliczeń wyemitowanych papierów wartościowych, z kredytów i pożyczek z lat ubiegłych. Oznacza to w rezultacie zakaz deficytu operacyjnego (bieżącego) budżetu JST (art. 242 ustawy o finansach publicznych ${ }^{27}$. Tym samym przedmiotowa reguła sankcjonuje rozgraniczenie budżetu na sekcję bieżącą oraz majątkową i wprowadza zasadę finansowania za pomocą deficytów budżetowych wyłącznie wydatków majątkowych (inwestycyjnych), a nie bieżących.

Natomiast IWZ jest wskaźnikiem określającym zasadniczo zdolność JST do spłaty zadłużenia. Opiera się na idei zindywidualizowanego dla każdej jednostki samorządu terytorialnego limitu kosztów obsługi zadłużenia, nawiązującego do wysokości wypracowanej nadwyżki operacyjnej wyliczonej za okres siedmiu lat poprzedzających rok budżetowy, w którym będą zaciągane zobowiązania dłużne. Formułę wyliczania wskaźnika przedstawia następujący wzór (art. 243 ust. 1 pkt 4 ustawy o finansach publicznych):

$$
\frac{(R+O)}{D b} \leq \frac{1}{7} \times \sum_{i=1}^{7} \frac{(\text { Dbei }- \text { Wbei })}{D b i}
$$

w którym poszczególne symbole oznaczają:

$R$ - to planowana na rok budżetowy łączna kwota z tytułu spłaty rat zobowiązań finansowych JST zaliczanych do tytułu dłużnego, z wyłączeniem kwot spłat kredytów i pożyczek oraz wykupów papierów wartościowych odpowiednio zaciągniętych lub emitowanych na pokrycie w ciągu roku przejściowego deficytu budżetu JST i zobowiązań krótkoterminowych, podlegających spłacie lub wykupowi w tym samym roku, w którym zostały zaciągnięte lub wyemitowane.

O - planowane na rok budżetowy wydatki bieżące na obsługę długu,

Db - planowane na rok, na który ustalana jest relacja, dochody bieżące budżetu pomniejszone o dotacje i środki przeznaczone na cele bieżące,

Dbei - dochody bieżące w roku poprzedzającym o i lat rok, na który ustalana jest relacja, pomniejszone o dotacje i środki o charakterze bieżącym na realizację programu, projektu lub zadania finansowanego z udziałem środków pochodzących z budżetu Unii Europejskiej,

Dbi - dochody bieżące w roku poprzedzającym o $i$ lat rok, na który ustalana jest relacja, pomniejszone o dotacje i środki przeznaczone na cele bieżące,

Wbei - wydatki bieżące w roku poprzedzającym o $i$ lat rok, na który ustalana jest relacja, pomniejszone o wydatki bieżące z tytułu spłaty rat zaciągniętych kredytów i pożyczek, wydatki bieżące na obsługę długu oraz wydatki bieżące na realizację programu, projektu lub zadania finansowanego z udziałem środków pochodzących z budżetu Unii Europejskiej.

Warto nadmienić, że zaprezentowana formuła IWZ znacznie się różni od jego wersji pierwotnej wprowadzonej w 2014 r. Zmiany i modyfikacje to rezultat wielu głosów krytycznych ze strony zarówno przedstawicieli środowisk naukowych, jak i reprezentantów środowisk samorządowych, odnoszących się m.in. do następujących wad pierwotnej wersji wskaźnika IWZ:

27 Ustawa z dnia 27 sierpnia 2009 r. o finansach publicznych (Dz.U. 2021, poz. 305, ze zm.). 
- zbyt krótkiego okresu branego pod uwagę przy jego wyliczaniu (pierwotnie były to trzy lata; w nowej wersji jest to siedem lat);

- wywierania „presji” na JST, by sprzedawały swój majątek (w pierwotnej wersji wzoru uwzględniało się dochody ze sprzedaży majątku - Sm; nie uwzględnia się już ich w aktualnej wersji);

- nieuwzględniania w pierwotnej konstrukcji IWZ skutków finansowych wykorzystywania przez JST niestandardowych instrumentów zaciągania długu, de facto analogicznych do tradycyjnych kredytów i pożyczek; od 2019 r. zmodyfikowanym limitem IWZ objęto również niestandardowe instrumenty finansowe.

Warto wspomnieć również o najnowszej liberalizacji analizowanych reguł fiskalnych, dokonanej w celu uelastycznienia budżetów samorządowych i zwiększenia przestrzeni fiskalnej dla JST w kontekście ograniczania negatywnych skutków bieżącego kryzysu pandemicznego COVID-19. Kluczowe tymczasowe zmiany w tym zakresie to:

- wyłączenie z limitu IWZ zobowiązań, które JST zaciągają w związku z ubytkiem w dochodach, wynikającym z wystąpienia pandemii COVID-19;

- wprowadzenie od 2021 r. zasady, zgodnie z którą przy wyliczeniach IWZ do wydatków bieżących nie zalicza się wydatków na obsługę zadłużenia;

- zwiększenie możliwości spłaty zadłużenia przez JST; przez ustalenie na 2021 r. i lata kolejne relacji ograniczającej wysokość spłaty długu JST można w budżecie pomniejszać wydatki bieżące o wydatki bieżące poniesione w celu realizacji zadań związanych z przeciwdziałaniem COVID-19;

- złagodzenie reguły fiskalnej dotyczącej wymogu równoważenia strony bieżącej budżetu JST dodatkowo o wartość planowanego ubytku w dochodach będącego skutkiem wystąpienia COVID-19.

\section{Polityczne determinanty długu JST}

W teorii ekonomii występuje wiele koncepcji teoretycznych nawiązujących do interakcji pomiędzy systemami ekonomicznymi i politycznymi ${ }^{28}$. Można w tym kontekście wskazać zwłaszcza nurt nowej ekonomii instytucjonalnej (ang. New Institutional Economy) ${ }^{29}$, w tym również związaną z nim teorię wyboru publicznego (ang. Public Choice Theory) ${ }^{30}$.

28 A. Wyszkowski, Ł. Zegarowicz, Ocena występowania politycznego cyklu budżetowego w Polsce, „Prace Naukowe Uniwersytetu Ekonomicznego we Wrocławiu" 2018, nr 509, s. 453, https://doi.org/10.15611/pn.2018.509.38.

29 Termin „nowa ekonomia instytucjonalna” został wprowadzony do literatury przedmiotu przez O.E. Williamsona. Charakterystyczne dla podejścia instytucjonalnego jest przywiązywanie szczególnej wagi do instytucji, zarówno formalnych, jak i nieformalnych.

30 Teoria wyboru publicznego, znana również pod nazwą ekonomicznej teorii polityki, jako nurt współczesnej ekonomii instytucjonalnej rozwinęła się przede wszystkim w Stanach Zjednoczonych. Jej główni przedstawiciele to J.M. Buchanan, W.A. Niskanen i G. Tullock. Teoria opiera się na założeniu, że zasadniczą cechą ludzkiej egzystencji jest permanentna konieczność dokonywania określonych wyborów (w przypadku decydentów publicznych - wyborów politycznych) w warunkach różnych ograniczeń, w tym ograniczeń instytucjonalnych. Kluczowym problemem jest niesprawność/zawodność rządu (ang. government failure), wynikająca z ułom- 
Związek pomiędzy ekonomią a polityką jest niezaprzeczalny i zawsze interesował ekonomistów. Uwagę przykuwał również dług publiczny jako kluczowa kategoria ekonomiczna, determinowana przez wiele uwarunkowań politycznych oddziałujących na decyzje zadłużeniowe podejmowane przez decydentów publicznych (rządowych i samorządowych). Nawiązuje do tego m.in. teoria politycznego cyklu budżetowego (ang. political budget cycle) dotycząca elekcyjnego cyklu budżetowego. Za twórcę wspomnianej koncepcji uważa się W.D. Nordhausa ${ }^{31}$. Uważał on, że działania decydentów politycznych ukierunkowane są przede wszystkim na zdobycie jak największej liczby głosów w wyborach politycznych. Bezpośrednio przed wyborami rządzący politycy podejmują więc intensywne działania stymulujące gospodarkę w celu krótkookresowego poprawienia jej stanu, a w rezultacie - zwiększenia swoich szans na reelekcję. Z kolei bezpośrednio po wygranych wyborach ci sami decydenci są zmuszeni diametralnie zmienić charakter prowadzonej wcześniej polityki publicznej, by zniwelować negatywne skutki ekspansywnej i nieracjonalnej ekonomicznie polityki przedwyborczej. Jak podkreśla P. Struś, o ile model Nordhausa eksponował przede wszystkim działania prowadzone w ramach ekspansywnej polityki monetarnej, o tyle współczesne badania koncentrują się na ekspansywnej polityce fiskalnej (zwiększanie wydatków publicznych, deficytów budżetowych oraz długu publicznego) $)^{32}$.

W aspekcie przedmiotowej problematyki badawczej za istotne należy również uznać prace naukowe A. Alesiny, nieżyjącego już amerykańskiego ekonomisty, w tym jego artykuł opublikowany w 1995 r. wspólnie z R. Perottim ${ }^{33}$. Autorzy, na podstawie badań empirycznych nad państwami OECD, identyfikują w nim sześć grup modeli charakteryzujących i systematyzujących polityczno-instytucjonalne uwarunkowania długu publicznego. Zaliczają do nich: ${ }^{34}$

- modele oparte na oportunistycznych decydentach i naiwnych wyborcach z iluzją fiskalną (ang. models based upon opportunistic policymakers and naive voters with fiscal illusion) - zgodnie z nimi naiwni wyborcy nagradzają w wyborach polityków bez zrozumienia (ani uczenia się z przeszłości), że ekspansywna polityka przedwyborcza najczęściej skutkuje powyborczymi recesjami, których koszty ponoszą podatnicy;

- modele redystrybucji międzypokoleniowej (ang. models of intergenerational redistributions) zakłada się w nich, że międzyokresowy charakter decyzji fiskalnych tworzy swoiste więzi międzypokoleniowe; zaciągany współcześnie dług publiczny jest spłacany przez przyszłe pokolenia; jednocześnie jednak reprezentanci tych pokoleń, mimo że nie brali udziału w podejmowaniu decyzji w sprawie wydatków i pożyczek, czerpią korzyści z dóbr publicznych sfinansowanych wcześniej za pomocą instrumentów dłużnych;

ności decydentów publicznych. Politycy w procesach decyzyjnych, również tych dotyczących zadłużenia, nie kierują się interesem publicznym, ale własnymi partykularnymi celami związanymi z reelekcją.

31 W.D. Nordhaus, The Political Business Cycle, „Review of Economic Studies” 1975, nr 42, s. 169-190.

32 P. Struś, Polityczno-instytucjonalne aspekty deficytu budżetowego, „Ruch Prawniczy, Ekonomiczny i Socjologiczny" 2008, nr 4, s. 173-174.

33 A. Alesina, R. Perotti, The Political Economy of Budget Deficits, „IMF Working Papers” 1994, nr 085, s. 1-28, https://doi.org/10.5089/9781451850680.001.

34 Ibidem, s. 6-24. 
- modele długu jako zmiennej strategicznej, łączącej obecny rząd z następnym (ang. models of debt as a strategic variable, linking the current government with the next one) - zgodnie z nimi partie polityczne sprawujące władzę próbują za pomocą deficytu i długu wpłynąć na decyzje fiskalne podejmowane w przyszłości przez kolejne rządy;

- modele rządów koalicyjnych (ang. models of coalition governments) - zakłada się w nich, że partie polityczne niebędące w stanie rządzić samodzielnie muszą tworzyć koalicje polityczne, w których zwykle wypracowanie racjonalnej polityki budżetowej jest znacznie trudniejsze niż w rządzie jednopartyjnym; w rezultacie rządy koalicyjne w szerszym zakresie przyczyniają się do powstawania oraz utrzymywania deficytów budżetowych i długu publicznego;

- modele interesów rozproszonych geograficznie (ang. models of geographically dispersed interests) - opierają się na założeniu, że decydenci publiczni w procesach decyzyjnych dotyczących zadłużenia zwykle przeceniają korzyści płynące z projektów publicznych realizowanych w swoich okręgach wyborczych w stosunku do kosztów ich finansowania; prowadzi to do wyższego niż optymalny poziomu wydatków publicznych w faworyzowanych przez decydentów okręgach wyborczych; w rezultacie rozkład geograficzny kosztów, korzyści i uprawnień decyzyjnych może mieć duże znaczenie dla budżetu zagregowanego i związanego z nim długu publicznego;

- modele, w których kładzie się nacisk na skutki działania instytucji budżetowych (ang. models emphasizing the effects of budgetary institutions) - zgodnie z ich założeniami poziom deficytu i długu publicznego uwarunkowany jest: prawami regulującymi ograniczenia fiskalne, $\mathrm{tj}$. regułami fiskalnymi, procedurami związanymi z przygotowaniem i uchwalaniem budżetu oraz zasadami regulującymi kwestie przejrzystości fiskalnej.

Jak zauważa A. Babczuk, pomimo że wspomniane powyżej polityczno-instytucjonalne modele zadłużenia są istotne dla rozwoju ekonomiki zadłużenia publicznego, trudno o jednoznaczne, empiryczne potwierdzenie ich poprawności ${ }^{35}$.

Celowe jest szersze nawiązanie do koncepcji iluzji fiskalnych (ang. fiscal illusions) ${ }^{36}$, polegających na kreowaniu przez polityków fałszywych wyobrażeń wyborców na temat możliwych wariantów demokratycznego wyboru. Termin ten wprowadził do teorii finansów publicznych wspomniany już wcześniej twórca teorii wyboru publicznego J.M. Buchanan. Uważał on, że w procesie wyborczym wyborcy faworyzują polityków, którzy realizują model ekspansywnej polityki fiskalnej, opierającej się na wzroście wydatków publicznych lub redukcji skali obciążeń podatkowych. W swoich pracach podkreślał też problem celowego ukrywania przez decydentów publicznych prawdziwych kosztów podatkowych związanych z ponoszonymi wydatkami publicznymi ${ }^{37}$. Władze publiczne przez tworzenie iluzji fiskalnych w odniesieniu zarówno do wydatków, jak i wpływów budżetowych eksponują i przeszacowują rolę wydatków publicznych,

35 A. Babczuk, Modele zadłużenia publicznego odwołujqce się do typu instytucji politycznych, „Ruch Prawniczy, Ekonomiczny i Socjologiczny" 2007, nr 3, s. 150.

36 Terminu tego po raz pierwszy użył na początku XX w. włoski ekonomista A. Puviani: idem, Teoria della illusione finanziaria, Palermo 1903.

37 Por.: J.M. Buchanan, Fiscal Theory and Political Economy, The University of North Carolina Press, Chapel Hill 1960, s. 59-64; J.M. Buchanan, Finanse publiczne w warunkach demokracji, PWN, Warszawa 1997, s. 160. 
a jednocześnie nie doszacowują wydatków ponoszonych ze źródeł prywatnych. W ten sposób starają się ukryć rzeczywisty, indywidualny udział podatników w całkowitym koszcie finansowania dóbr i usług publicznych, a tym samym przyczyniają się do sztucznego zawyżania popytu na te dobra i usługi, w konsekwencji zaś - do nadmiernej kreacji wydatków publicznych. Władze publiczne podejmujące decyzje w zakresie alokacji dóbr i redystrybucji dochodów kierują się kryteriami politycznymi (reelekcji) i traktują wydatki publiczne jako instrument walki politycznej z konkurentami. Przy świadomości, że wyborcy faworyzują rozrzutne władze publiczne (jest to jedna z hipotez iluzji fiskalnej R.E. Wagnera) ${ }^{38}$, wykazują nadmierną tendencję do kreowania wydatków publicznych, finansowanych najczęściej za pomocą instrumentów dłużnych.

Opisujący problem iluzji fiskalnych w kontekście długu lokalnego H.S. Banzhaf i W.E. Oates używają terminu „iluzja długu” (ang. debt illusion) i podkreślają, że podatnicy oceniają jako korzystniejsze dla nich finansowanie lokalnych programów publicznych za pomocą długu lokalnego niż z wykorzystaniem podatków lokalnych ${ }^{39}$. Wyborcy łatwiej akceptują wzrost lokalnego długu publicznego niż wzrost lokalnych obciążeń podatkowych. Władze samorządowe chcące uzyskać poparcie wyborcze są więc skłonne zastępować podatki samorządowe długiem (ang. substitution of taxes for debt) jako instrumentem finansowania lokalnych zadań publicznych. Australijski ekonomista J. Carmichael określa takie działania władz publicznych jako wykorzystywanie odroczonego podatku w formie długu (ang. using of deferred taxes in the form of debt) ${ }^{40}$.

Możliwości kreowania długu publicznego przez władze publiczne są ograniczane przez opisane wcześniej (w części Prawnofinansowe determinanty długu JST) reguły fiskalne limitujące zadłużenie. Politycy często więc decydują się na ukryte pożyczki (ang. hidden borrowing). Badacz T.C. Irwin zalicza je do tzw. forteli fiskalnych ${ }^{41}$, pozwalających na ominięcie obowiązujących limitów zadłużenia. W finansach samorządowych w Polsce przyjmuje to najczęściej formę „wypychania” długu poza budżet JST, tj. do spółek komunalnych ${ }^{42}$. W świetle polskiego prawa wspomniane spółki nie podlegają bowiem regulacjom ustawy o finansach publicznych, a w przypadku ich zadłużenia nie są stosowane obowiązujące limity zadłużenia JST ${ }^{43}$.

38 R.E. Wagner, Revenue Structure, Fiscal Illusion, and Budgetary Choice [w:] „Public Choice” 1977, t. 25, nr 1, S. 45-61.

39 H.S. Banzhaf, W.E. Oates, On Fiscal Illusion in Local Public Finance: Re-Examining Ricardian Equivalence and The Renter Effect, "National Tax Journal” 2013, t. 66, nr 3, s. 511-540.

40 J. Carmichael, Debt Versus Tax Financing of Government Spending: On Barro's Neutrality Theorem, „RBA Research Discussion Papers"1980, rdp8003.

41 Por.: T.C. Irwin, Accounting Devices and Fiscal Illusions, „IMF Staff Discussion Note” 2012, s. 5, https://doi. org/10.5089/9781475502640.006.

42 Por. M. Jastrzębska, Dług ukryty jednostek samorzadu terytorialnego - przyczyny, skutki, przeciwdziałanie, „Annales Universitatis Mariae Curie-Skłodowska. Sectio H. Oeconomia" 2017, t. 51, nr 4, s. 125-132, https://doi. org/10.17951/h.2017.51.4.125; M. Poniatowicz, Ukrywanie długu jednostek samorzadu terytorialnego w Polsce problem realny czy marginalny?, „Ekonomiczne Problemy Usług” 2011, nr 76, s. 203-216; A. Babczuk, Zadłużenie spółek komunalnych w Polsce. Próba oceny skali i zróżnicowania regionalnego, „Finanse Komunalne” 2012, nr 9, s. 5-16; M. Langer, Ukryte formy zadłużenia jednostek samorządu terytorialnego - próba oceny zjawiska, „Prawo Budżetowe Państwa i Samorządu” 2014, t. 2, nr 4, s. 75-86.

43 Niewątpliwą dysfunkcją polskich finansów samorządowych jest pozostawanie zbiorczego zadłużenia spółek komunalnych w Polsce poza polem obserwacji i monitorowania. Informacje o nowo zaciąganym długu oraz 
W literaturze przedmiotu podkreśla się też, że zdecydowanie bardziej podatne na manipulacje władzy publicznej są systemy finansów publicznych charakteryzujące się niską transparentnością. Nieprzejrzystość fiskalna stanowi podatny grunt dla iluzji fiskalnych, w tym zwłaszcza iluzji długu. Potwierdzają to m.in. badania naukowe M. Jastrzębskiej, a także E. Malinowskiej-Misiąg ${ }^{44}$. Dowodzą tego również obserwacje polskiej praktyki gospodarczej związanej z ekspansywnym wykorzystywaniem instrumentów dłużnych przez państwo, notabene niewidocznych w jego budżecie, w kontekście ograniczania negatywnych skutków bieżącego kryzysu pandemicznego COVID-1945.

\section{Ekonomiczno-społeczne determinanty długu JST}

Zdolność do zaciągania i obsługi długu każdego podmiotu korzystającego ze zwrotnych źródeł finansowania (w tym również JST) zależy od jego sytuacji finansowej i płynności finansowej (bieżącej i prognozowanej). Sytuacja finansowa podmiotu, który się zadłuża lub ma zamiar korzystać z długu jako źródła finansowania działalności, zależy od wielu determinant, na które ma on wpływ lub tego wpływu nie ma i do których musi się dostosować. Można je rozpatrywać w skali makro i mikro ${ }^{46}$.

Do determinant ekonomicznych, w tym finansowych, w skali makro należy zaliczyć przede wszystkim: poziom rozwoju gospodarczego kraju, poziom stopy inflacji i stopy bezrobocia, stopień rozwoju prywatyzacji i mechanizmów rynkowych, działalność społeczno-gospodarczą państwa, stan finansów publicznych. Ponadto sytuacja finansowa jednostki samorządu terytorialnego zależy od zakresu samodzielności finansowej, przyznanej jej na podstawie regulacji

o łącznym zadłużeniu spółek nie są nigdzie gromadzone, a tym bardziej upubliczniane. Związany z tym problem nieprzejrzystości finansów lokalnych można byłoby rozwiązać w relatywnie prosty sposób, np. przez wprowadzenie obowiązku informacyjnego JST w tym zakresie (np. w formule obligatoryjnych załączników dołączanych do uchwały budżetowej, sprawozdań finansowych itp.).

44 M. Jastrzębska, Jawność i przejrzystość finansów publicznych w kształtowaniu świadomości obywatelskiej [w:] Perspektywa ekonomiczna, finansowa i prawna kreowania wartości w gospodarce, red. P. Antonowicz, P. Galiński, P. Pisarewicz, Wydawnictwo Uniwersytetu Gdańskiego, Gdańsk-Sopot 2020, s. 147-160; M. Jastrzębska, Openess and Transparency of Fiscal Reporting in Poland - Assessment and Recommendation, "e-Finanse" 2018, t. 14, nr 3, s. 1-7, https://doi.org/10.2478/fiqf-2018-0015; E. Malinowska-Misiąg, Polski budżet w ocenie International Budget Partnership , „Kontrola Państwowa” 2017, numer specjalny 1, s. 22-37; E. Malinowska-Misiąg, Przejrzystość fiskalna a stabilność polskiego systemu finansów publicznych, „Kwartalnik Kolegium Ekonomiczno-Społecznego. Studia i Prace" 2017, nr 1, s. 31-44, https://doi.org/10.33119/kkessip.2017.1.2.

45 Wydatki publiczne z tym związane, uruchomione w ramach tzw. pakietów antykryzysowych, są w Polsce finansowane głównie przez Bank Gospodarstwa Krajowego oraz Polski Fundusz Rozwoju. Zadłużenia tych instytucji - zgodnie z polską sprawozdawczością budżetową - nie zalicza się do państwowego długu publicznego (PDP). W rezultacie na koniec 2020 r. zadłużenie polskiego sektora finansów publicznych liczone według metodologii krajowej było niższe o 224,3 mld zł (ok. 10\% PKB) w porównaniu z zadłużeniem liczonym według metodologii unijnej (EDP), https://www.gov.pl/web/finanse/zadluzenie-sektora-finansow-publicznych [dostęp: 26 listopada 2021 r.].

46 Por. M. Jastrzębska, Zarządzanie długiem jednostek samorzq̨du terytorialnego, Wolters Kluwer, Warszawa 2009, s. 111-117. 
prawnych stanowionych centralnie. Zakres władztwa dochodowego, w tym władztwa podatkowego oraz władztwa wydatkowego, swoboda dysponowania nadwyżkami finansowymi, ograniczenia prawne zadłużania się JST, poziom dochodów transferowych z budżetu państwa i stopień sfinansowania nimi wydatków na zadania JST mają więc istotny wpływ na sytuację finansową i płynność finansową JST. Wysoki stopień uzależnienia JST od władz centralnych oraz sytuacji budżetu państwa ogranicza ich samodzielność finansową, w tym zdolność do zaciągania i obsługi długu. Władze centralne liczą na to, że JST, dysponujące znaczącym potencjałem ekonomiczno-finansowym i wydajną bazą dochodów własnych, same będą poszukiwać środków na realizację zadań, w tym zwłaszcza zadań inwestycyjnych. Do determinant ekonomicznych w skali makro zaliczyć też należy ofertę instrumentów dłużnych dostępną na rynku finansowym, z której mogą korzystać JST, a także warunki stawiane przez dawców kapitału oraz zmiany rynkowych stóp procentowych i kursów walutowych.

Do determinant ekonomicznych, w tym finansowych, w skali mikro należy zaliczyć posiadane przez JST zasoby rzeczowe i finansowe. A zatem na sytuację finansową jednostki ma wpływ poziom jej potencjału dochodowego, potencjału inwestycyjnego, potencjału wytwórczego znajdującego się na jej terenie, a także zdolność do akumulacji środków oraz struktura własnościowa, rzeczowa i podmiotowa gospodarki samorządowej (w tym zdeterminowany przez te struktury charakter rynku lokalnego). Sytuacja finansowa JST w znacznym stopniu zależy od uwarunkowań naturalnych, takich jak wielkość JST. Z kolei wielkość jednostki samorządu terytorialnego determinuje jej politykę rozwoju, zdolność do taniego wykonywania zadań, a także funkcjonowanie demokracji samorządowej. Ważne jest też położenie JST - jednostki zlokalizowane w regionach biedniejszych i słabiej rozwiniętych zmuszone są do oszczędzania, natomiast te w regionach bogatych i wysoko rozwiniętych mają większy potencjał dochodowy i mogą więcej wydawać na siebie, w tym na inwestycje samorządowe ${ }^{47}$. Do uwarunkowań naturalnych mających wpływ na sytuację finansową JST należą też: struktura demograficzna ludności i jej zmiany, dostępne zasoby i walory naturalne, warunki klimatyczne. Istotny wpływ mają również skutki ujemne nagłych zmian warunków atmosferycznych (np. powodzie, susze), ponieważ wpływają na wzrost wydatków związanych z ich usuwaniem.

Na decyzje zadłużeniowe JST mają też wpływ determinanty społeczne. Można do nich zaliczyć: stopień rozwoju więzi międzyludzkich w ramach wspólnoty samorządowej, rozwój demokracji lokalnej, stopień upodmiotowienia społeczeństwa (poziom zaangażowania w życie obywatelskie), a także stosunek mieszkańców i podmiotów gospodarujących na terenie JST do podatków i opłat lokalnych, usług publicznych (zakres i sposób ich realizacji oraz poziom zadowolenia mieszkańców) i procesów politycznych (zarówno w JST, jak i w skali regionu, kraju). Ważne jest zróżnicowanie potrzeb zbiorowych społeczności samorządowych z zakresu użyteczności publicznej na szczeblu lokalnym i regionalnym. Demokratyzacja życia na poziomie społeczności samorządowych sprawia, że władze samorządowe muszą zabiegać o ich poparcie dla realizowanych programów i strategii, tj. sposobów i kierunków wydatkowania środków

47 Por. P. Swianiewicz, Modele samorząu terytorialnego w krajach Europy Zachodniej oraz Środkowowschodniejpróba generalizacji, „Studia Regionalne i Lokalne” 2002, nr 4, s. 49-67. 
publicznych, jak również metod gromadzenia środków finansowych na realizację zadań (np. poziom stawek podatków i opłat lokalnych, stosowane ulgi, zwolnienia, umorzenia, poziom zadłużenia, poziom wydatków inwestycyjnych i rodzaje realizowanych inwestycji samorządowych). Stąd prowadzenie przez JST systematycznych badań marketingowych w celu pozyskiwania informacji o potrzebach mieszkańców i o poziomie zaspokojenia tych potrzeb jest podstawą zwiększenia nie tylko racjonalności gospodarowania środkami finansowymi przezJST, lecz także efektywności wykorzystania środków ze zwrotnych źródeł finansowania na realizację zadań JST.

\section{Organizacyjno-zarządcze determinanty długu JST}

Do determinant długu jednostki samorządu terytorialnego, które w istotnym stopniu od niej zależą, należą determinanty organizacyjno-zarządcze. Niewystarczająca znajomość funkcjonowania mechanizmu rynku finansowego i brak umiejętności zarządzania powstałym długiem mogą prowadzić JST do nadmiernego zadłużenia i problemów z obsługą długu, a ostatecznie do wpadnięcia w pułapkę zadłużenia. Osoby podejmujące decyzje finansowe powinny brać pod uwagę konsekwencje ich realizacji, zarówno w krótkim okresie, jak i długim (o ile możliwe są do przewidzenia długofalowe skutki decyzji finansowych w momencie ich podejmowania), a także powinny zdawać sobie sprawę, co wywołało konieczność podjęcia określonych decyzji finansowych. Niestety, wciąż brakuje kadr profesjonalnie przygotowanych do gospodarowania publicznymi zasobami pieniężnymi (szczególnie w małych JST) według zasad i metod stosowanych w gospodarce rynkowej. Jednostki samorządu terytorialnego skupiają się przede wszystkim na planowaniu długu, zwłaszcza że jego poziom jest jednym z obligatoryjnych elementów wieloletniej prognozy finansowej. Planowanie długu nie może jednak zastąpić samodzielnie formułowanej i realizowanej przez JST polityki długu. Ponadto z reguły zbyt małą wagę JST przykładają do minimalizacji zarówno kosztów obsługi długu, jak i ryzyka związanego z korzystaniem z instrumentów dłużnych (problem świadomości ryzyka, jego pomiaru i podjęcia określonych działań w celu jego ograniczenia). Nie zawsze też rozumieją potrzebę wydłużania zapadalności długu oraz kontroli zmieniającego się ryzyka refinansowania długu ${ }^{48}$.

Problemem w obsłudze długu JST nie jest jedynie poziom wypłat z tego tytułu, ale brak umiejętności wyznaczania środków na spłatę długu (problem wypłacalności JST). A zatem bardzo ważne jest umiejętne rozłożenie w czasie spłaty zadłużenia w kolejnych okresach, aby obciążenie wydatkami i rozchodami z tego tytułu było mniejsze od środków finansowych, jakie jednostka może rocznie przeznaczyć na spłatę długu (z dochodów i przychodów). Wprawdzie jednostka samorządu terytorialnego, która utraciła płynność finansową i jest niewypłacalna, nie może być postawiona w stan upadłości, ale jej sytuacja finansowa stanowi problem dla Skarbu Państwa (np. pożyczki udzielane przez ministra finansów nadmiernie zadłużonym JST) i dla dawców kapitału.

Ważna jest przede wszystkim umiejętność zarządzania finansami JST, w tym zarządzania długiem i stosowania budżetu zadaniowego, wieloletniego planu finansowego, wieloletniego

48 Por. A. Kamiński, Dylematy dotyczq̨ce zadłużenia, „Wspólnota” 2013, nr 23, s. 38-40. 
planu inwestycyjnego, analizy sytuacji finansowej i płynności finansowej, metod szacowania ryzyka finansowego. Wykorzystanie tych instrumentów wymaga sprawnego przepływu informacji między JST a jednostkami jej podległymi, a także odpowiedniego poziomu wykształcenia służb finansowych w JST. Każda jednostka korzystająca ze zwrotnych źródeł finansowania powinna mieć komórkę zarządzającą długiem. Organizacja i rozmiary tej komórki powinny zależeć od wolumenu i struktury długu, przyjętej polityki długu oraz strategii zarządzania długiem. A zatem im większa jest jednostka samorządu terytorialnego i bardziej aktywna na rynku finansowym, tym struktura organizacyjna komórki zarządzającej długiem powinna być bardziej złożona. W zarządzaniu długiem JST bardzo ważne jest przestrzeganie standardów i korzystanie z tzw. dobrych praktyk. Standardy zarządzania długiem nie stanowią sztywnych norm prawnych, lecz powstają w wyniku długotrwałego procesu kształtowania się określonych praktyk w zakresie zarządzania finansami oraz oceny przydatności tych praktyk z punktu widzenia realizacji założonych celów. Jednostki samorządu terytorialnego korzystające z instrumentów zwrotnego finansowania powinny ${ }^{49}$ :

- określić przyczyny korzystania ze zwrotnych źródeł finansowania w krótkim i długim okresie oraz cele i kierunki wydatkowania środków z tych źródeł;

- zdefiniować uwarunkowania korzystania z instrumentów zwrotnego finansowania (zależne i niezależne od JST);

- ustalić skutki korzystania ze zwrotnych źródeł finansowania;

- określić zasady i kryteria wyboru instrumentów zwrotnego finansowania (cel przeznaczenia pozyskanych środków finansowych, charakter pożyczkodawcy, ryzyko związane z zastosowaniem danego instrumentu, terminy spłat i okres karencji, oprocentowanie, formy wymaganego zabezpieczenia, terminy emisji, kanały dystrybucji długu);

- opracować politykę zarządzania długiem oraz politykę zarządzania ryzykiem finansowym i określić: priorytety struktury długu JST w powiązaniu ze strategią rozwoju JST, np. minimalną liczbę źródeł finansowania zwrotnego, maksymalną kwotę finansowania zwrotnego od jednego podmiotu, maksymalną kwotę finansowania zwrotnego w walutach obcych, maksymalną kwotę finansowania zwrotnego przy stałym/zmiennym oprocentowaniu, całkowity poziom kosztów obsługi długu, który nie przekroczy x\% rocznych dochodów ogółem / dochodów własnych JST, limit zadłużenia w danym okresie (miesiącu, kwartale, roku);

- planować poziom zadłużenia w zależności od potrzeb finansowych i zdolności do obsługi długu oraz sytuacji na rynku finansowym (określenie maksymalnego poziomu zadłużenia w krótkim i długim okresie oraz dopasowanie go ex ante i ex post do indywidualnego wskaźnika zadłużenia);

- stworzyć zespół osób odpowiedzialnych za zarządzanie długiem JST w celu jego racjonalnego wykorzystania;

49 Por. M. Jastrzębska, Działania służące i niesłużqce efektywnemu zarzq̨dzaniu długiem jednostek samorzq̨du terytorialnego „Problemy Zarządzania” 2017, t. 15, nr 2(67), s. 149-150, https://doi.org/10.7172/1644-9584.67.8; M. Bitner, K. Cichocki, J. Sierak, Standardy zarządzania długiem na szczeblu lokalnym i regionalnym oraz ich wpływ na finansowanie infrastruktury, Instytut Badań Systemowych PAN, Warszawa 2013, s. 295-296. 
- monitorować poziom i strukturę zadłużenia - ocena zmian poziomu istniejącego zadłużenia w powiązaniu z szacowaniem możliwości zwiększenia poziomu długu; potrzebne są wystandaryzowane metody pomiaru długu dla każdej jednostki samorządu terytorialnego w celu ograniczenia ryzyka utraty płynności finansowej i minimalizacji kosztów obsługi długu;

- analizować obciążenia budżetu JST zobowiązaniami z tytułu obsługi długu (spłata odsetek i rat kapitałowych) oraz obliczać relację tych zobowiązań do wyniku budżetu JST (wskaźnik ten informuje, jaka część deficytu budżetowego wynika z konieczności spłaty zaciągniętego długu);

- dokumentować procedury zarządzania długiem i zarządzania ryzykiem związanym z zaciąganiem długu w ramach kontroli zarządczej.

\section{Wnioski}

Zaciąganie długu przez JST jest zdeterminowane wieloma czynnikami. Niełatwo odpowiedzieć na pytanie, które determinanty długu JST mają kluczowe znaczenie: czy prawnofinansowe i polityczne, czy ekonomiczno-finansowe i organizacyjno-zarządcze. Z pewnością istotną rolę w hamowaniu nadmiernego zadłużenia jednostki samorządu terytorialnego, zagrażającego jej bezpieczeństwu finansowemu, odgrywają regulacje prawne. W krajowych przepisach brakuje jednak unormowań dotyczących celowości zadłużenia JST (uzasadnienia zadłużania się), a konkretnie - wymogu określania przesłanek zaciągania długu, wynikających z przeprowadzonej analizy kosztów i korzyści wyboru źródeł finansowania przedsięwzięć inwestycyjnych, a także wymogu opracowania i wdrażania polityki finansowej, w tym polityki długu i strategii zarządzania długiem. Rzetelnie opracowane prognozy i analizy skutków podejmowanych decyzji dłużnych chroniłyby JST przed nadmiernym zadłużeniem i przeinwestowaniem. Powinno też nastąpić wzmocnienie w regulacjach prawnych odpowiedzialności za podjęcie błędnych decyzji. Ważne wydają się również działania na rzecz zwiększania przejrzystości długu JST. Jednym z nich mogłoby być wprowadzenie zasady dołączania (np. w formie załącznika) zarówno do uchwały budżetowej, jak i sprawozdania z wykonania budżetu informacji o zadłużeniu spółek komunalnych. Zachowaniu bezpieczeństwa finansowego JST sprzyjałoby również stworzenie „platformy dobrych praktyk w zarządzaniu finansami samorządowymi", w tym zarządzaniu długiem JST, jak to jest np. w Kanadzie i Stanach Zjednoczonych.

\section{Bibliografia}

Alesina A., Perotti R., The Political Economy of Budget Deficits, „IMF Working Papers” 1994, nr 085, https://doi. org/10.5089/9781451850680.001.

Babczuk A., Zadłużenie spółek komunalnych w Polsce. Próba oceny skali i zróżnicowania regionalnego, „Finanse Komunalne" 2012, nr 9.

Balaguer-Coll M.T., Prior D., Tortosa-Ausina E., On The Determinants of Local Government Debt: Does One Size Fit All?, „International Public Management Journal” 2016, t. 19, nr 4, https://doi.org/10.1080/10967494.2015.1104403.

Banzhaf H.S., Oates W.E., On Fiscal Illusion in Local Public Finance: Re-Examining Ricardian Equivalence and The Renter Effect, "National Tax Journal” 2013, t. 66, nr 3, https://doi.org/10.17310/ntj.2013.3.01. 
Bitner M., Cichocki K.S., Sierak J., Standardy zarządzania długiem na szczeblu lokalnym i regionalnym oraz ich wpływ na finansowanie infrastruktury, Instytut Badań Systemowych PAN, Warszawa 2013.

Borodo A., Samorząd terytorialny. System prawnofinansowy, LexisNexis, Warszawa 2006.

Brzozowska K., Partnerstwo publiczno-prywatne. Przesłanki, możliwości, bariery, CeDeWu, Warszawa 2013.

Buchanan J.M., Finanse publiczne w warunkach demokracji, PWN, Warszawa 1997.

Buchanan J.M., Fiscal Theory and Political Economy, The University of North Carolina Press, Chapel Hill 1960.

Bucovetsky S., Federalism, Equalization and Risk Aversion, „Journal of Public Economics" 1998, t. 67, nr 3, https:// doi.org/10.1016/S0047-2727(97)00076-5.

Carmichael J., Debt Versus Tax Financing of Government Spending: On Barro's Neutrality Theorem, „RBA Research Discussion Papers" 1980, rdp8003.

Ciupek B., Kania P., Determinanty regułfiskalnych w zarzqdzaniu zadłużeniem jednostek samorzqdowych, „Prace Naukowe Uniwersytetu Ekonomicznego we Wrocławiu" 2015, nr 404, https://doi.org/10.15611/pn.2015.404.03.

Cropf R.A., Wendel G.D., The Determinants of Municipal Debt Policy: A Pooled Time-Series Analysis, „Environment and Planning" 1998, t. 16, nr 2, https://doi.org/10.1068/c160211.

Filipiak B.Z., Dług jako determinanta stabilności systemu finansów samorządowych, „Kwartalnik Kolegium Ekonomiczno-Społecznego. Studia i Prace" 2017, nr 1, https://doi.org/10.33119/KKESSiP.2017.1.1.

Galiński P., Limitowanie długu jednostek samorzqdu terytorialnego, „Zarządzanie i Finanse” 2017, t. 15, nr 2.

Guziejewska B., Ograniczenia w zaciąganiu długu przez samorząd terytorialny - aspekty teoretyczne a rozwiqzzania w praktyce [w:] Podsektor samorządowy w sektorze finansów publicznych w warunkach akcesji Polski do Unii Europejskiej, red. L. Patrzałek, Wydawnictwo Wyższej Szkoły Bankowej, Poznań-Wrocław 2006.

Irwin T.C., Accounting Devices and Fiscal Illusions, „IMF Staff Discussion Note” 2012, https://doi. org/10.5089/9781475502640.006.

Jastrzębska M., Dług ukryty jednostek samorzqdu terytorialnego - przyczyny, skutki, przeciwdziałanie, „Annales Universitatis Mariae Curie-Skłodowska. Sectio H. Oeconomia" 2017, t. 51, nr 4, https://doi. org/10.17951/h.2017.51.4.125.

Jastrzębska M., Działania służące i niesłużq̨ce efektywnemu zarządzaniu długiem jednostek samorządu terytorialnego, „Problemy Zarządzania” 2017, t. 15, nr 2(67), https://doi.org/10.7172/1644-9584.67.8.

Jastrzębska M., Jawność i przejrzystość finansów publicznych w kształtowaniu świadomości obywatelskiej [w:] Perspektywa ekonomiczna, finansowa i prawna kreowania wartości w gospodarce, red. P. Antonowicz, P. Galiński, P. Pisarewicz, Wydawnictwo Uniwersytetu Gdańskiego, Gdańsk-Sopot 2020.

Jastrzębska M., Openess and Transparency of Fiscal Reporting in Poland - Assessment and Recommendation, "e-Finanse" 2018, t. 14, nr 3, https://doi.org/10.2478/fiqf-2018-0015.

Jastrzębska M., Zarzadzanie długiem jednostek samorzqdu terytorialnego, Wolters Kluwer, Warszawa 2009. Kamiński A., Dylematy dotyczace zadłużenia, „Wspólnota” 2013, nr 23.

Kiyosaki R., Lechter S., Rich Dad, Poor Dad: What the Rich Teach Their Kids About Money-That the Poor and Middle Class Do Not!, Warner Business Books, 2000.

Kopits G., Symansky S., Fiscal Policy Rules, International Monetary Fund, Washington 1998.

Krugman P., Cheating Our Children, "New York Times” 2013, March 28th, www.nytimes.com/2013/03/29/opinion/ krugman-cheating-our-children.html.

Lane T.D., Market Discipline, „IMF Staff Papers” 1993, t. 40, nr 1. 
Langer M., Ukryte formy zadłużenia jednostek samorzqdu terytorialnego - próba oceny zjawiska „Prawo Budżetowe Państwa i Samorządu" 2014, t. 2, nr 4.

Malinowska-Misiąg E., Polski budżet w ocenie International Budget Partnership , „Kontrola Państwowa” 2017, numer specjalny 1.

Malinowska-Misiąg E., Przejrzystość fiskalna a stabilność polskiego systemu finansów publicznych, „Kwartalnik Kolegium Ekonomiczno-Społecznego. Studia i Prace" 2017, nr 1, https://doi.org/10.33119/kkessip.2017.1.2.

Martinez-Vazquez J., Vulovic V., How Well Do Subnational Borrowing Regulations Work, „ADBI Working Paper Series" 2016, nr 563.

Nordhaus W.D., The Political Business Cycle , „Review of Economic Studies” 1975, nr 42.

OECD, Better Governance, Planning and Services in Local Self-Governments in Poland, Paris 2021, https://doi. org/10.1787/550c3ff5-en.

OECD and European Committee of the Regions, The Impact of the COVID-19 Crisis on Regional and Local Governments: Main Findings from Joint CoR-OECD Survey, November 2020.

Persson T.G., Federal Fiscal Constitutions: Risk Sharing and Moral Hazard, "Econometrica” 1996, t. 64, nr 3, https:// doi.org/10.2307/2171864.

Poniatowicz M., Dobry dług versus zły dług, czyli o specyfice zadłużenia sektora samorządowego [w:] Ekonomiczne i prawne uwarunkowania i bariery redukcji deficytu i długu publicznego, red. J. Szołno-Koguc, A. Pomorska, Wolters Kluwer, Warszawa 2011.

Poniatowicz M., Ukrywanie długu jednostek samorzadu terytorialnego w Polsce - problem realny czy marginalny?, „Ekonomiczne Problemy Usług” 2011, nr 76.

Puviani A., Teoria della illusione finanziaria, Palermo 1903.

Sierak J., Komunalna luka infrastrukturalna a możliwości budżetowe gmin w jej ograniczaniu, Oficyna Wydawnicza SGH, Warszawa 2019.

Singh R.J., Plekhanov A., How Should Subnational Government Borrowing Be Regulated? Some Cross-Country Empirical Evidence, „IMF Staff Papers” 2007, t. 53, nr 3.

Struś P., Polityczno-instytucjonalne aspekty deficytu budżetowego, „Ruch Prawniczy, Ekonomiczny i Socjologiczny” 2008, nr 4.

Szołno-Koguc J., Przyczyny oraz możliwości zadłużania się jednostki samorządu terytorialnego, „Annales Universitatis Mariae Curie-Skłodowska. Sectio H. Oeconomia" 2013, t. 47, nr 1.

Tanzi V., On Fiscal Federalism: Issues To Worry About, https://www.imf.org/external/pubs/ft/seminar/2000/fiscal/ tanzi.pdf.

Ter-Minassian T., Craig J., Control of Subnational Government Borrowing [w:] Fiscal Federalism in Theory and Practice, red. T. Ter-Minassian, International Monetary Fund, Washington 1997.

Wachowska J.A., Luka infrastrukturalna inwestycji publicznych w Polsce, „Ekonomiczne Problemy Usług” 2013, $\mathrm{nr} 108$.

Wagner R.E., Revenue Structure, Fiscal Illusion, and Budgetary Choice, „Public Choice” 1977, t. 25, nr 1.

Witkowski K., Inwestycje infrastrukturalne w realizacji usług publicznych, „Studia Lubuskie” 2011, t. 7.

Wojtach A., Uwarunkowania zdolności absorpcyjnej funduszy unijnych w administracji publicznej, „Zarządzanie i Finanse" 2012, R. 10, nr 3.

Wyszkowski A., Zegarowicz Ł., Ocena występowania politycznego cyklu budżetowego w Polsce, „Prace Naukowe Uniwersytetu Ekonomicznego we Wrocławiu" 2018, nr 509, https://doi.org/10.15611/pn.2018.509.38. 
Zahariadis N., The Politics of Risk-Sharing: Fiscal Federalism and the Greek Debt Crisis, „IJournal of European Integration" 2013, t. 35, nr 3, https://doi.org/10.1080/07036337.2013.774787.

\section{Akty prawne}

Ustawa z dnia 27 sierpnia 2009 r. o finansach publicznych (Dz.U. 2021, poz. 305, ze zm.). 